\title{
The Importance of Information Technology as a Strategic Resource for Hospital Management Process and the Management Skills Required for Managers
}

\author{
Jayr Figueiredo de Oliveira'
}

\begin{abstract}
The developed research debates which is the perception of the administrators and hospital area managers about the ideal professional competency profile that the leadership occupants must have had in front of the available IT resources. The general objective, therefore, consisted in uplevel the inquired ones perception regarding the ideal professional competency to fulfill management tasks within hospital environment. The research with descriptive nature consisted of a Survey that has involved 900 professionals from 36 hospital institutions both public and private from the health sector, and composed by two steps (discussion and questionnaire). The results pointed out that the Professional competency profile considered ideal would have been the attributes related to the knowledge and ability to strategic and operational planning, leadership ability and ethics attitude.
\end{abstract}

Keywords: Hospital, information technology, leadership, maneger, professional competency, strategic planning. JEL Codes: M100, M130, M160

Available Online: $26-05-2016$

This is an open access article under Creative Commons Attribution 4.0 License, 2016.

\subsection{INTRODUCTION}

Over the past 30 years, the growing pressure on business made the technologies executives, more strategic professionals and general practitioners. Serious and well-founded analysis of day-by-day aspects may lead to a good understanding on how possibly the world will be in the coming years. In the corporate environment the search is no different. After all, a correct forecast would mean millions of new customers being conquered, which justifies the huge investment that companies, from the most varied sectors, make in Research and Development (R\&D).

Much more than trying to predict new consumption and/or services trends it is essential that companies are concerned about their survival in a globalized and highly competitive market, as well as examine how business structures will be in the coming years (Porter, 2009). The profile changes in the entire

\footnotetext{
1.EAESP-FGV, Brazil. Email: jfigueiredo@usp.br
} 
Information Technology (IT) environment are a reflection of enterprise needs changes. In the past, technology was seek due to technical issues, with systems being created with a focus on productivity, in automation of processes. Today, the need of corporations is to innovate in their business, regardless of its niche of actuation (Castells, Fernandez-Ardevol and Linchuan Qiu, 2009).

In view of the current scenario of IT in companies and this globalized market in which we live, we can perceive its presence in all of the areas and their use in a more intense way, mainly by the organizations providing services. However, according to Albertin and Albertin (2009) the wide use of this tool and its strongly use by organizations has been characterized as a reality in several areas of the economy, which is considered as a basic condition for companies to survive and compete.

In this way, the health business also assumes new dynamic articulating "from doctors' offices and clinics, hospitals, laboratories and diagnostic centers and enterprises to medical care, health insurance, cooperative and self-management (...) so as to require a corporate management in these organizations" (Yamamoto, 2001, p. 15) and start to build knowledge in harmony with the modern management practices, currently under construction (Porter and Teisberg, 2007), having as main focus reform in fact the system to add value to all citizens, including those of low income, through the formulation of strategies focused on the learning process and obtaining relevant social results. (Porter and Teisberg, 2007, p. 25)

Thus, the research question of this study was: what is the perception of administrators and managers in the hospital field on the ideal profile of professional competence that the occupants of command positions should have facing the resources offered by ITs? The overall objective, therefore, was to raise the perception of respondents about ideal profile of professional competence for the exercise of managerial activities in the hospital area. The theoretical scenario was based mainly on Galer, Vriesendorp and Ellis (2005), Bitencourt (2001), Le Boterf (2003), Ruas (2005), Baldwin et al., (2008), among others.

\subsection{THEORETICAL SCENARIO}

In our society, the hospital falls under the conditions of the market, influenced by social and economic policies. It is a service provider in assistance for the population, having the obligation to remain faithful to the purposes of restoring and promoting health, within a good technical standard and a great level of humanization in its operational activities, says Bertelli (2004).

Thinking in management of a hospital is, before anything else, knowing deeply that subject, as well as the institution in which they work, having knowledge of the rules and routines of the services it renders, recognize their strengths and/or those that need to be improved to, from then, devise a plan clear and organized for simplification and efficiency of work. It is important, moreover, to define the form of management that will be adopted.

Since many authors advocate related ideas (Borba, Lisboa and Ulhôa, 2009; Galvão and Ricarte, 2012; Paes, 2011; Valle et al, 2010), it is believed that each hospital should provide clearly the molds of leadership and its organizational values, thus promoting, direct influence on the formation of their managers behavior (Borba and Lisboa, 2006).

"In the first instance, the company itself, in this case the hospital establishment, is responsible for a good leadership", presents Marras (2001, p. 38). For both, the organization needs to define the contour base lines of the ideal leader, should also implement managerial development programs to achieve the proposed objectives. On the other hand, should also take into account the individual characteristics of each manager, allowing the possibility of complementing these with their talents and personal characteristics, the basic profile of desired ideal leadership (Valle et al, 2010). 
Whereas, those talents and basic characteristics of personal skills of a manager, refer to subjectivity, to multi functionality and inaccuracy, being widely disseminated by the restructuring process (Hirata, 1996). To Zarifian (2001) the competence of individuals is due to the mobilization of their knowledge, skills and attitudes in situations faced at work. Thus, knowledge is a set of knowledge accumulated by a person in his personal and professional life, either through formal or informal learning actions; it is the technical mastery over certain content. Now the ability is related to the performance of any activity that involves the mobilization of this accumulated knowledge over time. The possession of these cognitive resources indicates that the individual knows how to do a particular task, work, etc. Within a given process. Finally, the attitude relates to social and emotional behaviors and attitudes of people and that are triggered in the context of the organization.

The question of the relationship between training and professional practice then became a source of concern for research and professional training entities as the traditional concept of qualification has been replaced by new visions in order to meet the changes and technological innovations where systemic vision and critical and reflective sense need to find their place.

For Bronckart and Dolz (2004) professional skills are developed throughout the life of the worker, being formed on the basis of learning in formal and informal settings. Possess knowledge and skills does not mean being competent, it is possible to have knowledge without knowing how to apply it, so the skills are not guaranteed by diplomas but developed and improved throughout life.

This means that in the knowledge and information society the possession of disciplinary knowledge, or professional-technical (formal qualifications, formal knowledge) are not enough, but the ability to mobilize them to solve and cope with contingencies in work situations. Thus, assume relevance, tacit or social skills and subjectivity of workers, unorganized components of the training include cognitive and behavioral skills (Hirata, 1996).

According to Longo (2003) the traditional model of management, Weber's inspiration is in crisis as soon as we felt the need to search for the so-called "Welfare State" and that is from the state of well-being itself that managerial style emerges. In this same line of thought Schwella (2005) points out that in the context of contemporary public or private administration some challenges are posed to managers such as globalization, the complexity of the problems, economic and social inequality, diversity, adoption of good governance the erosion of trust, among others. To meet these challenges they face, the author suggests that managers develop leadership skills for the effective performance of their activities.

Following this same line of thought Longo (2003) argues that there should be the professionalization of organizational leaders whose abilities should be diversified and based on a set of attributes, such as reasons, character traits, self-concept, attitudes or values, skills and cognitive and behavioral capabilities. These features indicate that the context of management includes, before an operational change, cultural change, values and principle implies that the necessary development of a group identity, when he says: ... It seems necessary to have sufficient critical mass of people who sees themselves as managers, building this perception from common model of management functions and in accordance with the basic features described, as well as from a distinctive set of professional skills, consistent with that model (Longo 2003, p. 28).

These suggestions of managers' professionalization make references to the set of learnings built throughout life, based on cognitive, affective and mobilization of adaptive skills and socialization capabilities. The notion of competence and formal qualification of the manager exceeds its recognition from a diploma which shall be replaced by qualification consisting of a set of skills that involves addition to technical capacitation, scientific training, values, skills and social behaviors.

Based on these statements are considered essential features in the professionalization of managers confront and meet the constant changes that occur in the organizational context, especially the financial 
and human resources, and materials present in several businesses, including the hospital institutions, knowing also the IT's resources that today are part of their routines. For Marchiori's view (2002) managers' functions are, diagnose demands for information and possibilities, define methodologies for solution, apply compatible technologies, choose professionals and suitable suppliers to work in partnership, as well as the mechanisms for measuring progress activity and its total and partial results. In other words, managers fit the analysis, interpretation and synthesis of internal and external organizations data. Thus, the hospital managers fail to make available information from hospitals with high added value, in fact useful in formulating strategies and decision making process.

The primary function of the hospital manager, then, is to provide a service and / or product information that is targeted, practical and attractive (Balaraman and Kosalram, 2013). The same author amplifies the vision above, stating that more than technical skills, the hospital manager should think and plan strategically, structuring politic coordination and analyzing markets and contexts, as well as any other manager, regardless of business area. For this it is required a high level of personal and professional mobility that allows it to act not only as an employee but as a consultant and advisor.

In turn, the hospital organization from the perspective of Picchiai (1998, p.9), is one of the most complex organizations, it adds a set of clinical, hotel, restaurant, pharmacy, laundry, laboratory and other services, besides, involves a number of specialties. Given the high level of complexity and the need to integrate information coming from various sectors is what justifies the usefulness of managed IT. In this case, the use of IT as a management tool, can set up a means of ensuring competitive advantage to the organization, in that it provides reliable information in a timely fashion so that decisions are assertive and timely (Kalil et al., 2009).

According to Schout and Novaes (2007) having reliable, current and relevant information is stated as an essential element to the definition of policies, practices and systems management and hospital services. In this sense Balloni (2005) highlights three vital functions of a technological information system (ITS): business operations and process, decision making and strategies in pursuit of competitive advantage support. That's because an ITS has the ability to convert internal and external raw data in hospital greatest administrative / managerial valuable information, which facilitate planning, control, coordination, analysis and internal decision-making organizations (Cunha and Silva, 2005).

According to Beal (2001) modern ITS offer unprecedented opportunities for companies to improve internal processes and services to patients (customers, end consumers), since it improves the quality and availability of information and knowledge important for hospitals, patients, health plans and providers. Under this view, Cunha and Silva (2005) states that health-related organizations cannot prescind from informatization, since the quality of health care also depend on well structured ITS. An ITS deployed in a hospital improves information management, consequently organizational management (management and care processes), avoiding rework and waste through an agile and flexible informational control.

Upon the following theoretical reference, one can structure to the present article, the content that defines the management competency definition such as a group description of: enterprises required and expected knowledge in reference to the capacity of the applicability of the mandatory knowledge to the hospital managers face to the IT resources within the hospital management process.

For the present research, was also considered that attitudes reflect the values of the individual, while constructs that mentally represent basic and universal human goals that guide the actions of individuals, which will be shown below.

\subsection{METHODOLOGY}

The descriptive research consisted of a Survey which involved 900 professionals from 36 public and private hospitals in the health field, in it most doctors, nurses and pharmacists majority incumbents 
coordinator, director, manager, head of department / sector supervisor and technicians from hospitals, government agencies and covenant / health plans from the cities of São Paulo, São Caetano do Sul, Santos, Campinas, Barueri, Sao Bernardo do Campo, Osasco and France, all belonging to the State of São Paulo; the cities of Londrina, Maringa, Curitiba, Ponta Grossa, are located in the State of Paraná; and the city of Rio de Janeiro, capital of the eponymous state.

Data collection took place in two main phases: First Phase - used focus groups (Cooper and Schindler, 2003, p.133) with leaders to identify and define the profile attributes of managerial competence: knowledge, skills and attitudes / values followed by content analysis (Flick, 2004, p.202); and Second Phase - of a quantitative nature carried out questionnaires for validation and prioritization of the attributes defined above.

It is noteworthy that in the first phase of focus group, discussions with 900 professional participants from 30 events (between courses and lectures) relating to development managers-leaders programs, promoted by NTGN companies were performed - Core Training in Business Management and JM Services and Training in Health, both installed in the Greater São Paulo region, however with courses offered throughout Brazil for identification and definition of attributes that should make up the profile of professional competence of hospital managers. A "focus group is a panel of people, led by a trained moderator - the researcher in this case - who meet - with the researched - for a period of 90 minutes to two hours" (Cooper and Schindler, 2003, p.133).

The role of the moderator is to use the principles of group dynamics to focus or guide the group in the exchange of ideas, feelings and experiences regarding a specific topic, which in the case of this research consisted in designing the competency profile. Focus groups had an average of five respondents who discussed among themselves the subject with the encouragement of the researcher. The result of the work of groups, obtained by content analysis, considering the categories: cognitive - knowledge; and behavior: skills and values / attitudes that appeared in more groups pointed to the profile of professional competence of hospital managers.

Second Phase - structured questionnaires, with 352 individuals chosen for convenience - occupants of management positions in hospitals - among participants in the first stage of the research, for prioritization of attributes defined. The questionnaire consisted of closed and open questions. The closed questions were composed of the attributes defined in the previous phase where 5 items were to be selected and classified according to levels of the Likert scale: (5) Extreme importance (4) Very important, (3) Fairly important, (2) Important and (1) Minor importance. The open questions referred about the possibility of adding new attributes to the profile, and the question: In your undergraduate degree in health (Medicine, Nursing, Pharmacy, etc.), there were some discipline which embraced the study of the skills indicated by you as priorities for your performance as manager? The analysis of data from the closed questions was made with use of QM for Windows software, with the tabulation of responses, allowing the evaluation of the perception of respondents.

\subsection{ANALYSIS AND DISCUSSION}

\subsection{FIRST STAGE - RECOGNITION AND DEFINITION OF PROPERTY}

Related to knowledge, cognitive indicator shows notes linked to theoretical knowledge, conceptual, fundamental guide to good practice. It was identified and defined in this variable ten different properties.

Table 01: Definition of the variables related to Knowledge

\section{Knowledge}

Area / Healthcare

(policies, system, market)

\section{Definition}

Knowledge of strategic imprint on the market/society in which the Company operates, including customers, competitors, suppliers, and partners. 


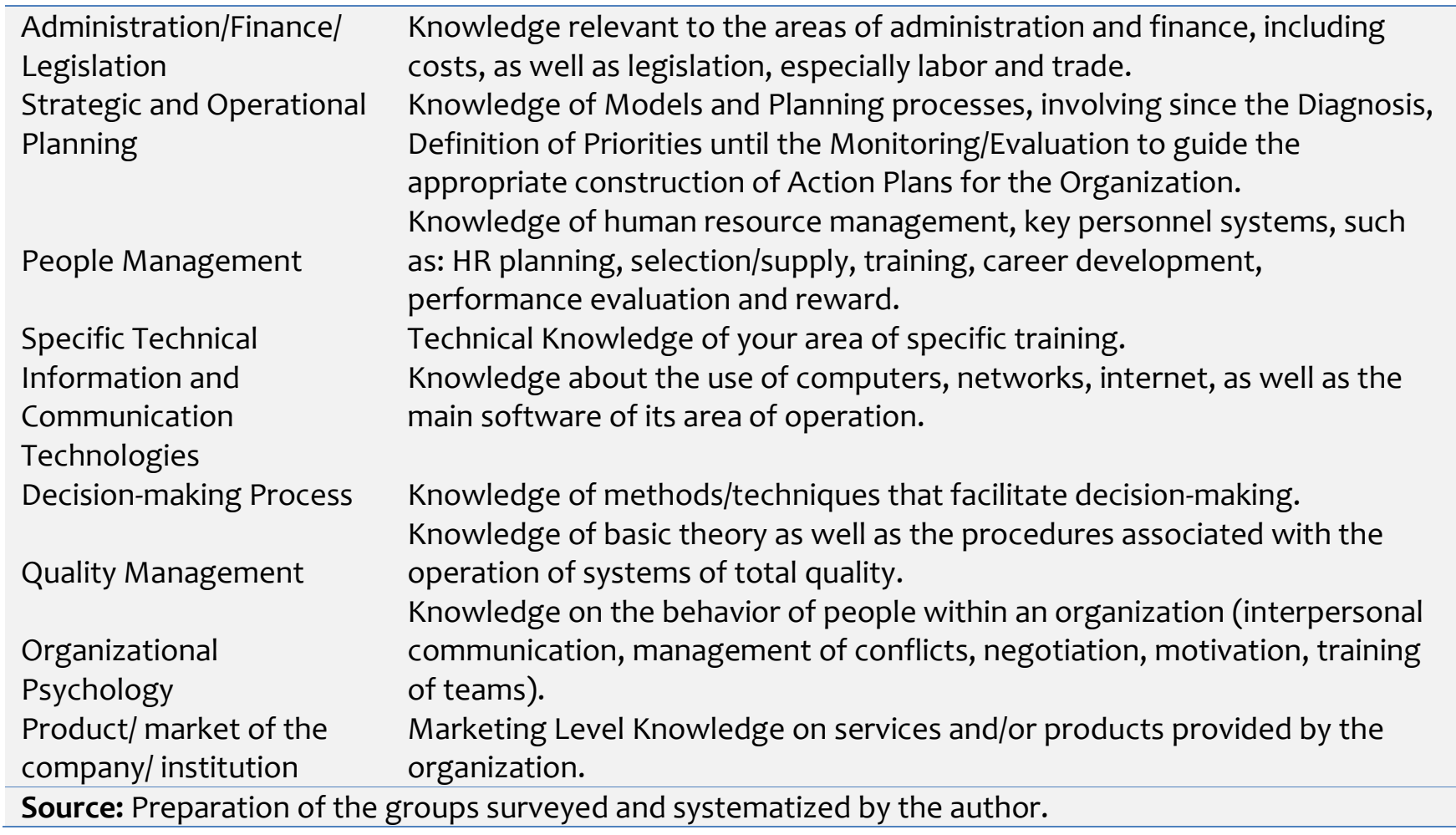

The A behavioral indicator, refers to the ability, denoting the know-how, ie the ability to apply previous theoretical knowledge. It was identified and defined in this variable ten different properties.

\begin{tabular}{|c|c|}
\hline \multicolumn{2}{|r|}{ Table 02: Definition of the variables related to skills } \\
\hline Ability & Definition \\
\hline Planning & $\begin{array}{l}\text { Ability to define and share goals, strategies and tactics for the administrative } \\
\text { process. }\end{array}$ \\
\hline Organization & $\begin{array}{l}\text { Ability to manage the administrative process, as well as to define the } \\
\text { different roles of the team members, including the distribution of activities, } \\
\text { tasks and responsibilities. }\end{array}$ \\
\hline Leadership & $\begin{array}{l}\text { Ability to influence and mobilize the working group, in order to achieve } \\
\text { objectives oriented toward the common good. } \\
\text { Ability to define actions/take attitude after analysis of alternatives, and that }\end{array}$ \\
\hline Decision & \\
\hline Communication/listening & $\begin{array}{l}\text { Ability to listen to superiors, employees, customers, suppliers and partners, } \\
\text { give and receive feedback, as well as to make himself understood, aiming to } \\
\text { facilitate the integration between the people involved and positively } \\
\text { influence the work environment. }\end{array}$ \\
\hline Analysis and Synthesis & $\begin{array}{l}\text { Ability to criticize and synthesize data and information on processes and } \\
\text { people, in order to meet objective elements that allow for an adequate } \\
\text { decision-making. }\end{array}$ \\
\hline Teamwork & $\begin{array}{l}\text { Personal ability that consists of the ability to fit easily with the other } \\
\text { members of the team, to negotiate and resolve conflicts, and to convert in } \\
\text { factor of integration of the team as a whole, with emphasis on excellence of } \\
\text { interpersonal relations. }\end{array}$ \\
\hline Creativity / Innovation & $\begin{array}{l}\text { Ability to generate new ideas (Creativity), as well as to promote their } \\
\text { implementation (Innovation). }\end{array}$ \\
\hline Implementation & $\begin{array}{l}\text { Capacity to implement the action plans drawn up, aiming at the effective } \\
\text { achievement of the desired results. }\end{array}$ \\
\hline $\begin{array}{l}\text { Inspiration and } \\
\text { Motivation of the Team }\end{array}$ & $\begin{array}{l}\text { Ability of the leader to create conditions conducive to inspiration and } \\
\text { motivation for his team, in constant search of high moral group. }\end{array}$ \\
\hline
\end{tabular}

Source: Preparation of the groups surveyed and systematized by the author. 
Yet behavioral indicator B, makes reference to the attitude, meaning wanting to be / make guided decisions and own motivations, i.e. personal, reflecting the values of the individual. It was identified and defined in this variable ten different properties.

\begin{tabular}{|c|c|}
\hline \multicolumn{2}{|r|}{ Table 03: Definition of the variables related to attitudes } \\
\hline Attitude & Definition \\
\hline Ethical & $\begin{array}{l}\text { Absolute respect for others, honesty and justice in decisions, and } \\
\text { consistency between the discourse and practice. }\end{array}$ \\
\hline Self-Reliant & $\begin{array}{l}\text { Awareness of their own limitations (humility) and their fortresses (trust), } \\
\text { passing a security posture and balance for your team. }\end{array}$ \\
\hline & Relentless Pursuit of conditions necessary to overcome challenges and \\
\hline Settled & achieve results, at personal and professional level. \\
\hline & Opening to listen/accept different opinions, as well as to understand the \\
\hline Flexible & $\begin{array}{l}\text { constant changes that generate the need for organizational changes. } \\
\text { Response, at optimum level, the set of Assignments of Responsibility, with a }\end{array}$ \\
\hline Responsible & $\begin{array}{l}\text { high degree of correspondence to the expectations of the Organization in } \\
\text { relation to its person. }\end{array}$ \\
\hline Server/Careful & $\begin{array}{l}\text { Awareness of the importance of Serving/ Take Care of led and the } \\
\text { customers/users. }\end{array}$ \\
\hline Comp & $\begin{array}{l}\text { Commitment and involvement with the Mission, Business Results and } \\
\text { institutional, as well as with the People in Your Organization. }\end{array}$ \\
\hline Self-motivated & $\begin{array}{l}\text { Enthusiasm at a high level, evidenced by the courageous stance of } \\
\text { overcoming the challenges of day-to-day. }\end{array}$ \\
\hline Visionary & $\begin{array}{l}\text { Preview of scenarios (dreams) to where you want to lead the Organization } \\
\text { and the Team and willingness to share these dreams with your work group. } \\
\text { Availability for Wanting to learn always (quest for self-development), as well }\end{array}$ \\
\hline Learner/Educator & as Concern with the development of all of the staff (educational role). \\
\hline
\end{tabular}

Galer, Vriesendorp and Ellis (2005) consider the powers (a) management - planning, organizing resources, implementation and execution of the work and monitoring results; and (b) leadership explore, focus, align and mobilize personnel, and inspire and motivate the team, that respondents chose among the ten most important skills of the leader manager, according to the description of the attributes, those who are more related to management such as planning, management and decision making. The Organizational Psychology attribute would signal to the leadership competency.

Second, Pena and Ndiaye (2002) there is tuning with the technical dimension whose main attribute specific knowledge of an area of knowledge.

With respect to behavioral indicators for skills and attitudes, there is enough similarity to the references presented for both managerial skills and for leadership. However, there is a similarity with Araújo (2012) with regard to the dimensions: Administrative - ability to plan and organize; Psychosocial - ability to interact constructively in the dynamics of inter-relationships; and political dimension of the exercise of power - the ability to make decisions and the ability to influence and mobilize the working group.

According to the components of the profile manager nowadays established by Oderich (2005) in the Chang and Hassabelnaby (2014) it was found, considering the attribute and its description: systemic and strategic vision / strategic and operational planning, personal / self-trusting domain, ability to work in teams / teamwork, creativity, flexibility, innovation, ethical behavior and ability to learn, to lead and educate / learner / educator.

Whereas the model of Araújo (2012), it was found mostly similar with the attributes: knowledge of the context; listening skills, creativity and inspiration; and values / attitudes as increased ability to adapt to 
the social system / flexibility, passion for wisdom / learner-educator, examination of values / ethical stance.

In the first phase of the research the identification and definition of the professional competence of the manager of the hospital area profile was taken. The systematization of the data obtained in the Survey was taken by the researcher. It is observed that the profile developed by researchers has line with prior research, cited in the theoretical foundation of this work, pointing to the fact that the hospital manager, coming from Leadership Development Programs, was already incorporating the concepts of competence to his speech.

\subsection{SECOND PHASE - PRIORITIZATION OF PROPERTIES}

The second stage of the research aimed to prioritize the most important properties in the view of respondents from managerial competence profile systematized by the researcher.

\subsubsection{CHARACTERIZATION OF RESPONDENTS}

\begin{tabular}{|c|c|c|c|}
\hline \multicolumn{4}{|c|}{ Table 04: Academic Training } \\
\hline & Type of Training & Quantity Quoted & Frequency $\%$ \\
\hline \multirow{9}{*}{ Graduation } & Medicine & 142 & $40.3 \%$ \\
\hline & Nursing & 82 & $23.3 \%$ \\
\hline & Dentistry & 8 & $2.3 \%$ \\
\hline & Pharmacy & 56 & $15.9 \%$ \\
\hline & Physiotherapy & 6 & $1.7 \%$ \\
\hline & Occupational Therapist & 4 & $1.1 \%$ \\
\hline & Nutrition & 14 & $4.0 \%$ \\
\hline & Other & 40 & $11.4 \%$ \\
\hline & Total & 352 & $100.0 \%$ \\
\hline \multirow{5}{*}{$\begin{array}{l}\text { Post- } \\
\text { Graduation }\end{array}$} & Specialization & 256 & $72.7 \%$ \\
\hline & Masters & 42 & $11.9 \%$ \\
\hline & Doctorate & 16 & $4.5 \%$ \\
\hline & None & 38 & $10.8 \%$ \\
\hline & Total & 352 & $100.0 \%$ \\
\hline
\end{tabular}

Respondents are mostly: physicians (40.3\%), followed by nurses (23.3\%) and pharmacists (15.9\%) which would point the reality of the occupation of management positions in healthcare. Respondents mostly have specialization courses (72.7\%).

\begin{tabular}{lrr}
\hline & Table 05: & \\
\hline Gender & Quantity Quoted & Frequency $\%$ \\
\hline Male & 144 & $40.9 \%$ \\
Female & 208 & $59.1 \%$ \\
\hline TOTAL & 352 & $100 \%$ \\
\hline
\end{tabular}

The subjects are distributed among individuals of both genders.

\begin{tabular}{lrr}
\hline & Table 06: Workplace & \\
\hline Workplace & Quantity Quoted & Frequency \% \\
\hline Hospital & 142 & $40.3 \%$ \\
Government Agency & 96 & $27.3 \%$ \\
Arrangement/Health Plans & 78 & $22.2 \%$ \\
Particular & 36 & $10.2 \%$ \\
TOTAL & 352 & $100 \%$ \\
\hline
\end{tabular}




\begin{tabular}{lrr}
\hline & Table 07: Workplace & \\
\hline Position/Function & Quantity Quoted & Frequency \% \\
\hline Coordinator & 104 & $29.5 \%$ \\
Director & 78 & $22.2 \%$ \\
Manager & 60 & $17.0 \%$ \\
Head of Service & 56 & $15.9 \%$ \\
Head of Sector & 10 & $2.8 \%$ \\
Supervisor & 28 & $8.0 \%$ \\
Technical & 16 & $4.5 \%$ \\
Not specified & 0 & $0.0 \%$ \\
\hline TOTAL & 352 & $100 \%$ \\
\hline
\end{tabular}

Respondents work mostly in hospitals (40.3\%), government agencies (27.3\%) and cooperative class (22.2\%), exercising management activities.

\begin{tabular}{lrr}
\hline & Table 08: Length of service & \\
\hline Service Time & Quantity Quoted & Frequency \% \\
\hline Less than 05 years & 44 & $12.5 \%$ \\
From 05 to 15 years & 94 & $26.7 \%$ \\
From 16 to 25 & 118 & $33.5 \%$ \\
With 26 years in before & 96 & $27.3 \%$ \\
\hline TOTAL & 352 & $100 \%$ \\
\hline
\end{tabular}

\begin{tabular}{lrr}
\hline \multicolumn{2}{c}{ Table 09: Experience Management } \\
\hline Managerial Experience & Quantity Quoted & Frequency \% \\
\hline Less than 02 years & 42 & $11.9 \%$ \\
From 02 to 05 years & 86 & $24.4 \%$ \\
From 06 to 10 & 96 & $27.3 \%$ \\
With 11 years onward & 128 & $36.4 \%$ \\
\hline TOTAL & 352 & $100 \%$ \\
\hline
\end{tabular}

Respondents are mostly professionals with over 05 years of service time and the exercise of managerial activity. Respondents can be characterized in general as professionals in medicine, nursing and pharmacy, with specialization courses exercising more than 05 years in management positions in hospitals.

\subsubsection{COMPETENCY PROFILE MANAGEMENT}

The validation of the competency profile and prioritization of attributes recorded the following results.

\begin{tabular}{lr}
\hline \multicolumn{2}{c}{ Table 10: Knowledge } \\
\hline Knowledge & Frequency\% \\
\hline Strategic and Operational Planning & $20.0 \%$ \\
Health Sector & $14.0 \%$ \\
Organizational Psychology & $11.0 \%$ \\
People Management & $10.5 \%$ \\
Specific technical & $100 \%$ \\
Ory Decision Process & $100 \%$ \\
Quality Management & $100 \%$ \\
Administration / Finance & $8.0 \%$ \\
Information Technology & $4.5 \%$ \\
Product & $20 \%$ \\
\hline TOTAL & $100 \%$ \\
\hline
\end{tabular}


Was considered most important knowledge, strategic and operational planning, followed by knowledge of the healthcare industry and organizational psychology. Knowledge of personnel management, specific technical, decision-making and quality management process were considered equally important.

The lowest relevant knowledge was considered the marketing about services and / or products provided by the organization.

The testimonies corroborate the necessity of academic curricula contemplate disciplines of managerial field:

- "Unfortunately the university [academic training] proves to be quite limited to technical and scientific issues showing up below the requirement of the market" (nurse);

- "The university is overly technicist, not corresponding to the demands of the market and society in general. Lack of focus on everyday problem-based learning. There are few activities that generate ratings of attitude and skills "(pharmacist);

- "The course curriculum does not prepare us to assume management positions" (physician);

- "The university should prepare their students for leadership and management, a fact that does not happen today" (physician);

- "There is a clear need to incorporate a new managerial mindset to health professionals" (physician);

- "As is the practice in some courses in the health field, such as nursing, there is a clear need to introduce the topic Health Management in the curriculum of all courses" (physician);

- "The nurses are better prepared since graduation, to manage" (nurses);

- "Unfortunately my undergraduate degree was very much related to the field of dentistry, there was then an undergraduate technical vision that even cared about the public sector, would form us to be doctors of private clinics" (dentist).

It is observed that regardless of training, respondents acknowledge that the academy prepares technical experts, there's need to incorporate new disciplines to the curriculum as has been happening with some courses in the area of health, as quoted in Nursing.

The appreciation of the strategic and operational planning may signal that health care is lacking this knowledge and at the same time aware of their need. It is also observed that the knowledge focused in the area of Information Technology, are still ignored by most health professionals. For many of these professionals, technological resources are focused only on electronic medical records (EMR)s, in their majority, repudiated by doctors, but somehow heeded by nursing managers (according to reported by these, by their obligation). Other technological resources stay at criteria of professionals who work directly with the specific diagnostic images technological resources. In turn, managers of hospital administrative areas represent over $70 \%$ in an amount of $4.5 \%$ frequency shown in Table 10 - Knowledge using the technological resources of information in performing their daily tasks, showing that professionals (doctors, nurses, etc.), are not familiar with and encouraged throughout his academic training to, know, use and manage the resources of information technology.

\begin{tabular}{lr}
\hline \multicolumn{2}{c}{ Table 11: Skills } \\
\hline Skills & Frequency\% \\
\hline Lead & $20.0 \%$ \\
Organization & $15.0 \%$ \\
Communication & I Listening \\
to Learn & $13.0 \%$ \\
Planning & \\
Decision & $12.0 \%$ \\
Teamwork & $11.0 \%$ \\
Execution & $9.0 \%$ \\
Inspiration and Motivation & $6.0 \%$ \\
Analysis and Synthesis & $5.5 \%$ \\
& $4.5 \%$ \\
\hline
\end{tabular}




\begin{tabular}{lr}
\hline Creativity / Innovation & $3.0 \%$ \\
\hline TOTAL & $100 \%$ \\
\hline
\end{tabular}

The skills considered most important were: leadership, organization, communication / listening, planning and decision.

In free testimonies it was found that the healthcare courses traditionally prioritize the technical component:

- $\quad$ "The course [of medicine] does not prepare professionals as human beings, but as technicians in each area." (Physician);

- $\quad$ "It should be considered as a priority investment in human relations from the period of training of professionals for the success of the actions taken by the institutions" (physician);

- "The course is extremely technical, with courses geared to make the student a competent person, and there isn't any focus for the study and knowledge of subjects that develop social and human capacity of the student" (pharmacist);

- $\quad$ "In the undergraduate course we just learn to be technical and not know anything about the reality that we will find out there, including dealing with people of various levels of knowledge, belief and races; only in graduation our world focuses on college and not make an awareness, after all we are all human, we have problems, conflicts, bills to pay, live in the world and not of it "(physiotherapist).

The interviewees expressed the need to develop "human skills" and a doctor argues that "lead, anticipate, dream, motivate, decide, act and plan, attitudes are inherent to all healthcare professionals, managers, and should be part of the curriculum grid ". Observes the recognition of changes, even subtle the testimony of another doctor who declares: "Only with the advent of humanization of health courses and the very action of professionals we headed to the scope of human beings, their relations, aspirations, defects, qualities, etc.. Now is our chance."

\begin{tabular}{lr}
\hline \multicolumn{1}{c}{ Table 12: Attitudes } \\
\hline Attitudes / Values & Frequency\% \\
Ethics & $20.0 \%$ \\
Involved & $17.0 \%$ \\
Easy going & $15.0 \%$ \\
Persevering & $11.0 \%$ \\
Responsible & $10.0 \%$ \\
Learner / educator & $100 \%$ \\
Self-confident & $50 \%$ \\
Self-motivated & $4.5 \%$ \\
Idealistic. & $4.5 \%$ \\
Server / Careful & $3.0 \%$ \\
\hline TOTAL & $100 \%$ \\
\hline
\end{tabular}

Regarding attitudes, the highlight was the ethical attitude in professional practice, i.e., absolute respect for others, honesty and fairness in decisions, and consistency between discourse and practice, followed by involvement, flexibility, perseverance, responsibility and attitude of learner and educator.

\subsection{FINAL CONSIDERATIONS}

The new social and technological demands highlight the need for building new strategic management profiles that can meet expectations and add value to reality. In this situation learning, incorporating the proper use of the remarkable capabilities of information technology and leadership development become crucial. In health the learning processes for the development of hospital clinical managers have 
been going to fill this gap, albeit slowly. This work revealed the perception of respondents about the professional competence profile considered ideal for the exercise of management activities in healthcare with emphasis on the attributes related to the knowledge and skill of strategic and operational planning, leadership skills, and ethical. It was further observed that there is an effective preparation of these professionals by the educational institutions and not a mandatory use imposed by the hospital authorities in the use of these technological resources in their daily professional activities. The presumption established that the students from learning processes are able to define a profile of managerial competence in line with state of the art of Directors was established.

This study sought to highlight the desired profile manager for the hospital, regardless of the niche of actuation and in this sense, bringing to light the importance of creating a diagnostic tool for training needs of this person to the extent of alignment between mission, institutional strategy and people management as well as greater integration between subsystems in the human resource management and the presence in effective use afforded by technological resources. Therefore this research limitation brings us back to a reflexion, in reference to the practical application verification at work environment situation of the acquired knowledge in the learning process of health related managers, as well as the need of a deeper study in the political competency dimension, investigating power abuse, autonomy and decision level, and influence capacity in enterprise's actions in order to see the health related issues within society as a whole and contemplating the group of citizens.

\section{REFERENCES}

Albertin, A. L.; Albertin, R. M. M. (2009). Tecnologia de informação e desempenho empresarial. São Paulo: Atlas.

Araújo, A. C. C. (2012) Análise das Competências dos gestores hospitalares de Campina Grande - PB. Paraíba: Universidade Estadual da Paraíba - Centro de Ciências Sociais Aplicadas.

Balaraman, P.; Kosalram, K. (2013) E - hospital management \& hospital information systems - changing trends. I. J. Information Engineering and Electronic Business, 1, 50-58

Baldwin, T. et. al. (2008). Desenvolvimento de habilidades gerenciais. Rio de Jjaneiro: Elsevier.

Balloni, A. J. (2005) Por que Gestão em Sistemas e Tecnologias de Informação? vll.2. Revista de Informação e Tecnologia, Campinas, p.1-3, 05 jan Disponível em: <http://www.ccuec.unicamp.br/revista/infotec/artigos/GESITI_FINAL.pdf> Acesso em: 03/09/2012

Beal, A. (2001) Introdução à Gestão de Tecnologia da Informação. DIponivel em: <http://2beal.org/ti/manuais/GTI_INTRO.PDF> Acesso em: 17/09/2011

Bertelli, S. B. (2004) Gestão de pessoas em administração hospitalar. Rio de Janeiro: Qualitymark, 2004.

Bitencourt, C. C. (2001). A gestão de competências gerenciais: a contribuição da aprendizagem organizacional. Tese de doutorado. Universidade Federal do Rio Grande do Sul. Escola de Administração. Programa de pós-graduação. Porto Alegre.

Borba, V. R.; Lisboa, T. C. (2006) Teoria geral de administração hospitalar. Rio de Janeiro: Qualitymark.

Borba, V. R.; Lisboa, T. C.; Ulhôa, W. M. M. (2009) Gestão administrativa e financeira de organizações de saúde. São Paulo: Atlas.

Bronckart, J. P.; Dolz, J. (2004) A noção de Competência: qual é sua pertinência para o estudo da aprendizagem das ações de linguagem? In: DOLZ, J.; OLLAGNIER, D. et al. O enigma da competência em educação. Porto Alegre: Artmed.

Castells, M.; Fernandez-Ardevol, M.; Linchuan Qiu, J. (2009). Mobile communication and society a global perspective. MIT Press.

Chang, K. J.; Hassabelnaby, H. R. (2013) The Influence of Ownership on Strategic Cost Management: Evidence from U.S. Hospitals. AAA 2014 Management Accounting Section (MAS), Disponível em: <http://papers.ssrn.com/sol3/papers.cfm?abstract_id=2297082\#\#>. Acesso em: 25/07/2014.

Cooper, D. R.; Schindler, P. S. (2003) Métodos de Pesquisa èm Administração. Porto Alegre: Bookman.

Cunha, F. J. A. P.; Silva, H. P. (2005) Gestão da Informação no Hospital e a Integração de Sistemas de Informação em Saúde: um Estudo em Hospitais de Salvador - BA. Salvador: Instituto de Ciência da 
Informação,

UFBA.

Disponível

em:

http://www.inovarh.ufba.br/pub/publicacao/dissertacaofranciscopedroza.pdf. Acesso em: 25/08/2014.

Flick, U. (2004) Uma introdução a pesquisa qualitativa. Porto Alegre: Bookman.

Galer, J. B.; Vriesendorp, S.; Ellis, A. (2005) Managers who lead. Cambridge: Management Sciences for Health.

Galvão, M. C. B.; Ricarte, I. L. M. (2012) Prontuário do paciente. Rio de Janeiro, Guanabara Koogan.

Hirata, H. (1996) Da polarização das qualificações ao modelo da competência. In: Ferretti, C. J.; Dagmar, M. L.Z.; Felícia, R .M. \& Franco, M. L. P. B. (Coord.). Novas tecnologias, trabalho e educação: um debate multidisciplinar. Vozes, Petrópolis.

Kalil, A. L. L. et. al., (2009). Avaliação de Sistemas de Informações em Hospitais. In: Seminário Nacional de Sistemas Industriais E Automação, 4 ed.., Belo Horizonte, MG: Cefet/MG. p.1, 10. Disponível em: <http://ssia.cefetmg.br/artigoscompletos/04_AvaliacaoDeSistemasDelnformacoesEmHospitais.pdf> Acesso em: 03/09/2013.

Le Boterf, G. (2003). Desenvolvendo a competência dos profissionais. Porto Alegre: Artmed.

Longo, F. (2003) A consolidação institucional do cargo de dirigente público. Revista do Serviço Público, Ano 54, n.2, abr-jun, p.7-33.

Marchiori, P. Z. (2002) A ciência e a gestão da informação: compatibilidades no espaço profissional. Ci. Inf. [online]. 2002, vol.31, n.2, pp. 72-79. ISSN 0100-1965. DISPONÍVEL em: <http://www.scielo.br/pdf/ci/v31n2/12910.pdf> Acesso em: 17/09/2013.

Marras, J. P. (2001) Administração de Recursos Humanos: do operacional ao estratégico. 3. ed. São Paulo: Futura, .

Paes, L. R. A. (2011) Gestão de operações em saúde: para hospitais, clínicas, consultórios e serviços de diagnósticos. São Paulo: Atheneu.

Pena, A. D.; Ndiaye, M. (2002) Developing hospital efficiency-cost control measures. World Hospitals \& Health Services V. 38 N. 3, IHF official journal.

Picchiai, D. (1998) Mudança em instituições hospitalares: análise do processo e estudo da ação do administrador hospitalar. São Paulo: Escola de Administração de Empresas de São Paulo, Fundação Getúlio Vargas. (Série Relatórios de Pesquisa, n.4) disponivel em: <http://virtualbib.fgv.br/dspace/handle/10438/3119> Acesso em: 12/09/2012.

Porter, M. (2009). COMPETIÇÃO. Rio de Janeiro: Campus.

Porter, M. E.; Teisberg, E. O. (2007). Repensando A Saúde. Porto Alegre: Bookman.

Schout, D.; Novaes, H. M. D. (2007) Do registro ao indicador: gestão da produção da informação assistencial nos hospitais. Ciênc. saúde coletiva [online]. vol.12, n.4, pp. 935-944. ISSN 1413-8123. disponível em: <http://www.scielosp.org/pdf/csc/v12n4/12.pdf> Acesso em: 30/06/2014.

Schwella, E. (2005) Inovação no governo e no setor público: desafios e implicações para a liderança. Revista do Serviço Público, Ano 56, n.3, jul-set,, p.259-276.

Valle, A. B.; Monat, A. S.; Amaral, A. F.; Marques, E. P. (2010) Sistemas de informações gerenciais em organizações de saúde. São Paulo: FGV.

Yamamoto, E. (2001). Os novos médicos administradores. São Paulo: Futura.

Zarifian, P. (2001) Objetivo Competência: por uma nova lógica. São Paulo: Atlas. 